\title{
THE ORIGINS OF TERRACING IN THE SOUTHERN LEVANT AND PATCH CULTIVATION/BOX FIELDS
}

\author{
SHIMON GIBSON $^{1}$ AND RAFAEL Y. LEWIS ${ }^{2}$ \\ ${ }^{I}$ Department of History, University of North Carolina at Charlotte, e-mail: \\ sgibso34@uncc.edu \\ ${ }^{2}$ Department of Archaeology,University of Haifa, e-mail: rafilewiss@gmail.com
}

Received: $16^{\text {th }}$ June 2017, Accepted: $9^{\text {th }}$ November 2017

\begin{abstract}
This paper looks at various suggestions relating to what incipient and early forms of terracing might have looked like, and goes on to suggest that some of the earliest terraces in the southern Levant may have emerged from horticultural practices, and more specifically the cultivation of olive trees within sunken patches of soil on rocky hillslopes (referred to as "patch cultivation" or "box fields"). This phenomenon may be traced back to the Chalcolithic period ( $4^{\text {th }}$ millennium B.C.E), if not to earlier times.
\end{abstract}

Keywords: terraces; patch cultivation; box fields; cup-marks; Chalcolithic period; landscape archaeology; southern Levant

\section{INTRODUCTION}

Visitors to the highlands of the southern Levant are often struck by the beauty and extent of the serried agricultural terraces which line the slopes, and by the sheer effort which must have gone into building them. Questions are asked about their antiquity and origin, and these are subjects often debated by landscape investigators dealing with the Levant and eastern Mediterranean countries. There is however uncertainty as to the methods that might be employed for dating terracing, and less is known about the original appearance of incipient terracing than one would like. We suggest that "patch cultivation" or "box fields" preceded the establishing of the earliest slope terraces in the highlands of the southern Levant (i.e. Israel/Palestine).

\section{The DATING OF TERRACES}

Research on terracing at highland locations in the southern Levant has highlighted certain methodological difficulties, most notably the problem of dating. A variety of methods have been advanced for the dating of terracing, and the consensus is that the task is not an easy one. The idea that an entire system of terraces can be dated solely based on a handful of potsherds is methodologically unsound.

Recently, the optically stimulated luminescence (OSL) method has been advocated as a system for dating terraces (Davidovich et al., 2012; Gadot et al., 2016; Porat et al., 2017), but there are serious drawbacks to this method (Gibson, 2015; Gibson \& Lewis, 2017). It can 
tell us about the date of the final use of terraces (in most cases this was Ottoman to early $20^{\text {th }}$ century), but not about when they were first built and their overall history. Those using this dating procedure have exacerbated the problem by ignoring other sources of dating evidence (Gadot et al., 2015: 119).

Undoubtedly, the best method for investigating terraces must be Landscape Archaeology owing to the underlying comprehensive approach it takes and the overall flexibility it allows for the examination and analysis of data (Gibson, 2003; Wilkinson, 2003).

When engaged in establishing the age of terraces, the task begins by first determining the extent of the phenomenon within a chosen region or hillslope, and it is not easy to establish where one terrace system stops and another begins. Some terrace systems have an aggregate pattern and others a planned arrangement with a more regular design. Some systems are responsive to the local terrain, others are not. Terraces are built, will collapse, and are then rebuilt over thousands of years: continuity is definitely the norm. Given areas of terraces are sometimes associated with features of known age, such as farm buildings, installations (oil and wine presses), cisterns, and roads, and these will enormously help dating efforts. Field boundaries and stone fences are sometimes found separating areas of terracing with ancient boundaries seen "fossilized" within extant modern boundaries. A comprehensive study of the density and distribution of potsherd scatters can be undertaken on the upper surfaces of terraces, and some of these sherd scatters may turn out to be the result of ancient manuring practices.

The excavation of test pits within terraces and next to key adjacent features is crucial to this method, and can serve as a "control" for results obtained in landscape surveys (Gibson, et al., 1991).

\section{EARLY SUgGESTIONS RELATING TO THE ORIGINS OF TERRACING}

Speculation as to the origins of terracing worldwide began in the $19^{\text {th }}$ century and continues to the present day.

In 1916, W. J. Perry published a survey on the geographical distribution of agricultural terraces worldwide. Like his mentor G. Elliot-Smith, Perry was a diffusionist and believed the practice of artificially built-up and irrigated terraces was spread by an immigration of builders of megalithic structures originating, in the first place, from Egypt (Perry, 1916: 1, distribution map on p. 2). Whilst Perry's views are no longer accepted, the data included in his paper is still of interest. The general points which emerge from his study, include: (1) terraces are dependent on rainfall and/or irrigation water; (2) terracing with a facing of stone walls often occur in areas where the soil cover is at a minimum, and the rock surface is exposed; (3) the expenditure of labor in the construction of terraces is always very high; (4) soils and fertilizing materials for terraces were sometimes brought from great distances; and (5) terracing is sometimes concentrated on north-facing slopes of hills. Perry's mentor Elliot-Smith opined that terraced cultivation originated in southern Arabia, as a modification of Mesopotamian and Egyptian agricultural regimes (Perry, 1916: 24).

There are several classic researches dealing with the origins of terracing published in the $20^{\text {th }}$ century, among them an important seminal article from 1961 by J. E. Spencer, a professor of geography at the University of California (Los Angeles), written together with his graduate student G. A. Hale. In this study, they put forward the notion that terracing reflects the technological ability human beings have in improving their natural landscape, in contradiction to the prevailing view, popular at the time, that terracing was the outcome of the influence of the environment over human agricultural endeavor. 
Spencer and Hale suggested that terracing originated in several parts of the world and from these geographical centers was then spread further afield (1961: map on p. 33). They postulated that the oldest dry-field terraces originated in the Near East (c. 2000 B.C.E.), and were then diffused to other parts of the Old World. Spencer and Hale's work was quite influential and research on terracing was stimulated in other parts of the world (for example, Wright, 1962; Wheatley, 1965; Allen, 1970; Allen, 1971; Donkin, 1979), and in Israel as well (Ron, 1966).

Spencer and Hale suggested that the origin of terraces should be sought in the marginal semi-arid regions of the Near East (1961: 7, 14; cf. Donkin, 1979: 131). However, terracing in the deserts of the southern Levant cannot be shown to be earlier than the Iron Age II ( $7^{\text {th }}$ century B.C.E.), though some terracing near the Dead Sea is said to be from the Pottery Neolithic period (Kuijt et al., 2007). Spencer and Hale also suggested that the earliest terraces with stone walls must have been crudely executed, low in height, and built on relatively slight slopes (1961: 180), but this is contradicted by the discovery at Sataf, west of Jerusalem, of an agricultural terrace of Early Bronze Age date (late $4^{\text {th }}$ millennium B.C.E) which was relatively well constructed and was built on a very steep slope (Gibson et al., 1991).

In the southern Levant, there was much speculation among scholars in the 1970s and later, particularly among biblical historians, that the invention of terracing had to have been the work of early Israelites (c. 1200 B.C.E.) (Albright, 1961: 113; Ron, 1977: 226; de Geus, 1975: 69). This approach began changing in the 1980s (Hopkins, 1985: 186; Finkelstein, 1988: 202, 309) with archaeological work challenging the link made between the first use of terracing and the Israelites, and it was shown that terracing existed in the central highlands a couple of thousand of years beforehand (Gibson, 2001).

\section{Patch Cultivation OR Box FieldS}

The significance of the phenomenon of cultivating trees in sunken irregularities on rocky hillslopes, referred to here as "patch cultivation" or "box fields," has not been fully recognized hitherto by researchers dealing with the practice of ancient highland agriculture in the southern Levant. These fields are found on rocky slopes that are usually largely devoid of soil cover, owing to the earlier removal of woodland and other types of human intervention (e.g. rock quarrying).

These box fields are seemingly natural irregular depressions in the rock surfaces of hillslopes, sufficiently broad and deep enough to accommodate the root systems of one or sometimes two trees, usually olive trees. While limited in size, they constitute levelled cultivable soils on sloping rocky ground. They have been observed in Israel/Palestine, and in Jordan, and some are still used by traditional farmers today. Examples of box fields in the Israel/Palestine highlands, are notable in the hills of central Galilee, in the vicinity of Nazareth, in the upper western Galilee (Pfann et al., 2007: 61, Fig. 33) (Fig. 1), in the Judean and Hebron hills, and in the foothills to the west and north-west of Jerusalem, and particularly around Modi'in (Fig. 2). 
Fig. 1: Tree growing out of a box field on a rocky slope at Nazareth in the lower Galilee mountains, Israel. Excavation project undertaken by Ross Voss and Stephen Pfann (Photo courtesy Stephen Pfann)

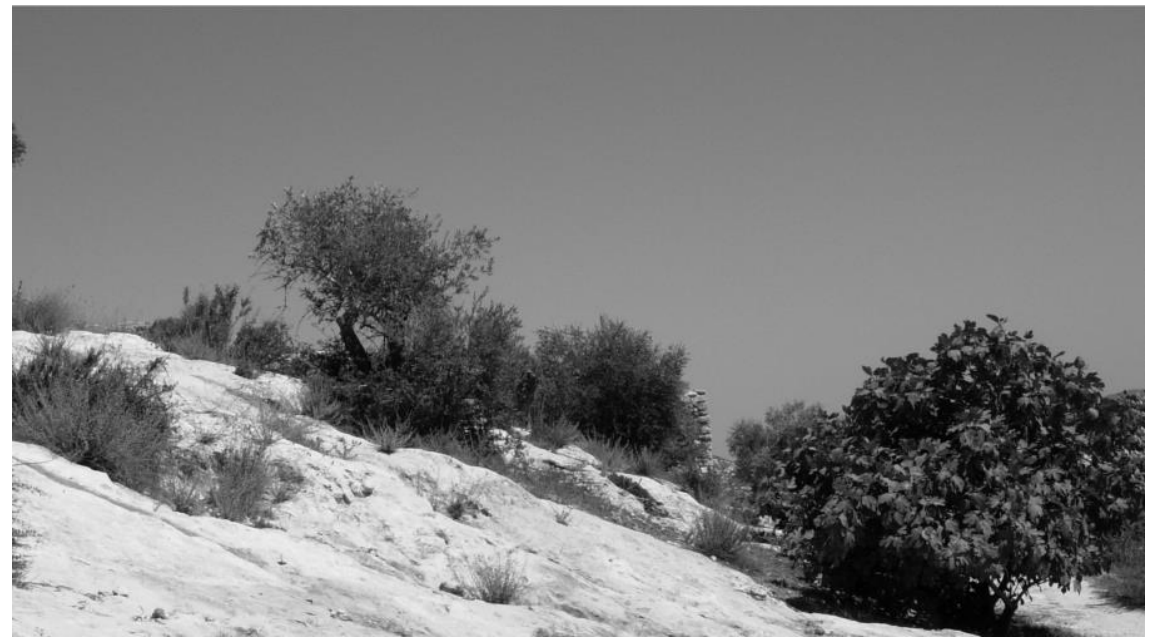

Fig. 2: Area of patch cultivation on a rocky slope (designated Shimshoni) in Modi'in in the western central foothills of Israel. IAA excavation project led by Shimon Gibson and Egon Lass. (Photo Sandu Mendrea, courtesy IAA)

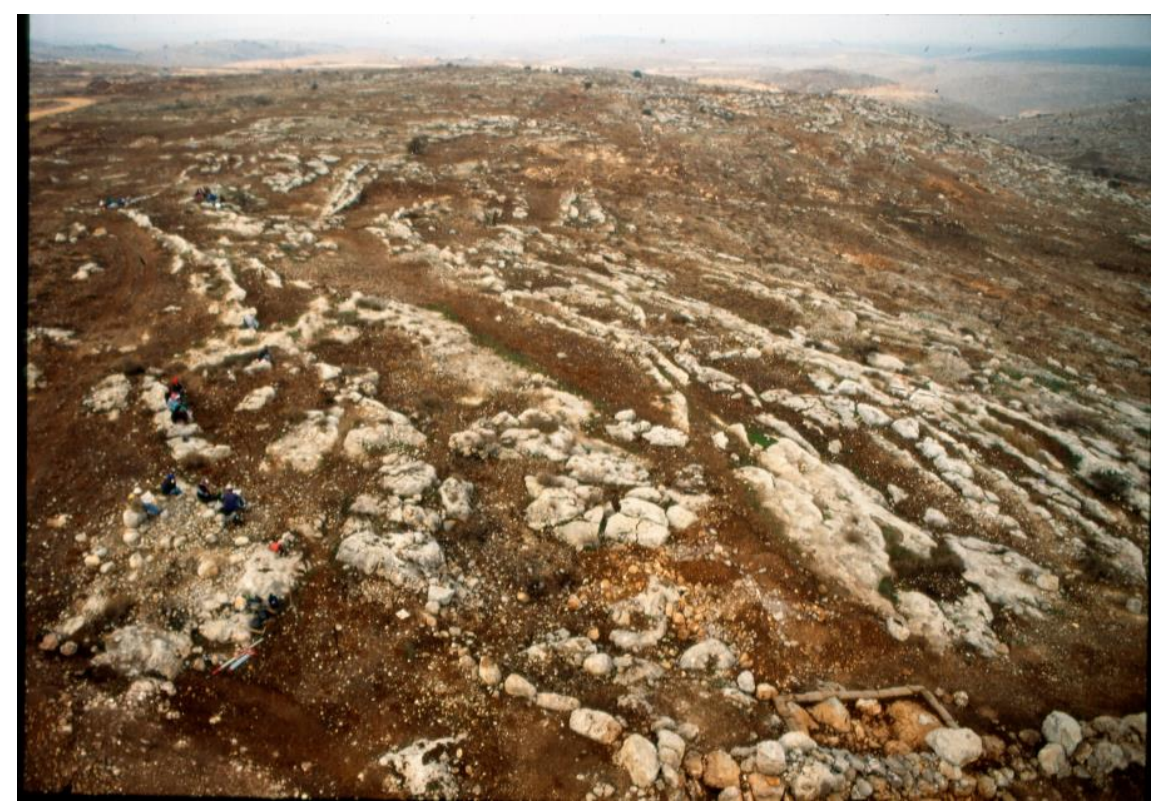

Owing to the "natural" appearance of box fields, they have hardly been studied in landscape archaeology projects. However, several of these box fields were excavated during work conducted around the modern city of Modi'in in the mid-1990s (Gibson, 2003: 8-9), revealing incised scoring to the surface of the underlying bedrock along their edges, caused by frequent use of agricultural implements, such as hoes or adzes on digging sticks. In 
excavations conducted at Giva't Titura in Modi'in, box fields were observed next to rocky outcrops with adjacent groups of agricultural installations, notably groups of circular vats and oval/oblong cup-marks/grooves from the Chalcolithic period, and these were situated on the slope above a settlement from that period (Figs. 3-4). The cup-marks were used for crushing the olives, and the vats for the extraction of small quantities of olive oil through vertical pressure under large stones. Similar installations associated with box fields were noted elsewhere in Modi'in, and these too have been dated to the Chalcolithic period (Van den Brink, 2008).

Fig. 3: Cupmarks on eastern slope of Horvat Titora with adjacent box or patch cultivation fields in Modi'in, Israel. (Photo Shimon Gibson)

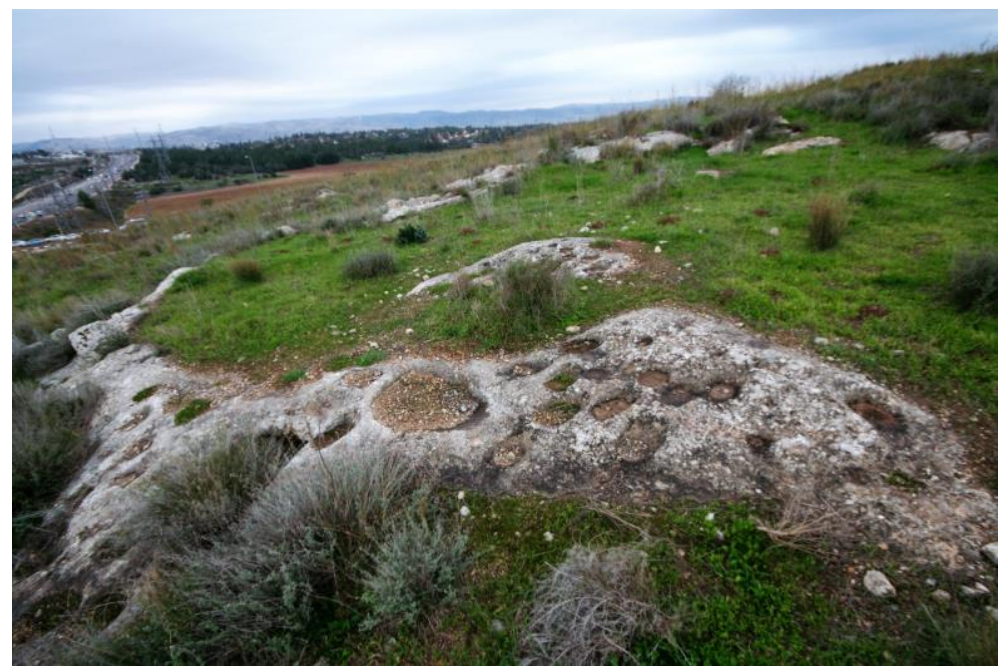

Fig. 4: Chalcolithic cupmarks in association with box or patch fields at Horvat Titora in Modi'in. Excavation project led by Shimon Gibson, Rafael Y. Lewis and Rona Avissar. (Photo Shimon Gibson)

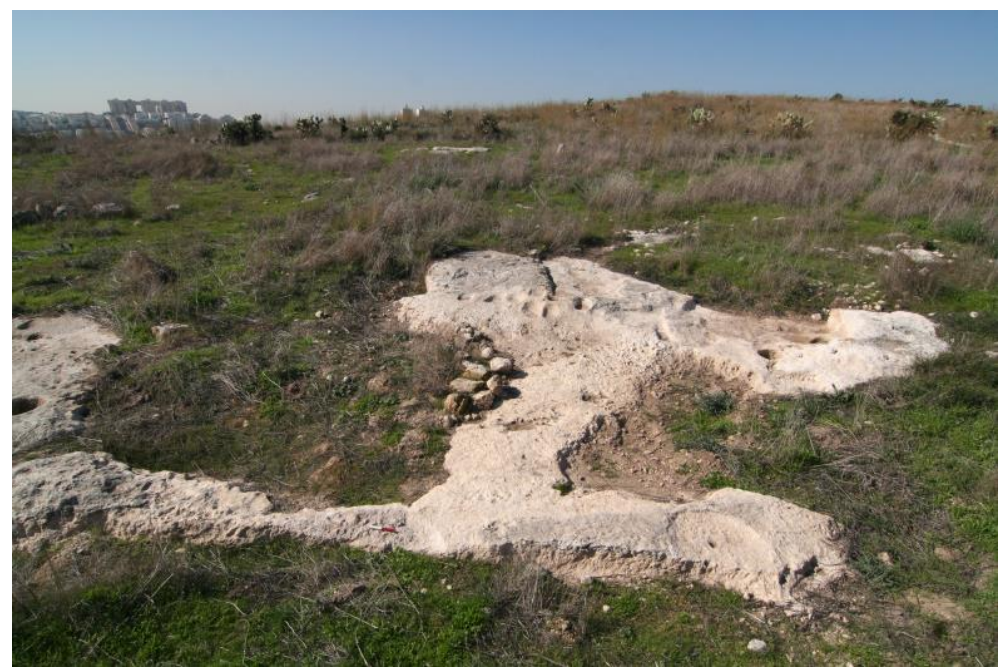


Box fields were also recorded as a phenomenon on the hillslope of Sataf, west of Jerusalem. During excavations at this site the remains of houses and installations dating from the Chalcolithic period were found adjacent to two springs of water, and owing to the very steep angle of the hillslope there can be no doubt that some form of retained fields had to have existed there during that period (Gibson et al., 1991). Indeed, an agricultural terrace from the Early Bronze I was excavated at the site, and it too may have been a development of a box field. Additional box fields were noted on the rocky hillslopes adjacent to the agricultural village from the Chalcolithic period at Khirbet es-Sauma'a situated to the north-east of Jerusalem (Gibson \& Rowan, 2006).

\section{CONCLUSIONS}

Clearly, on methodological grounds, the dating of agricultural field systems, specifically terraces in highland regions, is a complicated procedure (Frederick \& Krahtopoulou, 2000; Fall et al., 2012; Galletti et al., 2013; Bevan et al., 2013; Korobov \& Borisov, 2013; Gibson, 2015). The assumption that terraces can only be dated when found in direct association with single-period farmhouses, or, alternatively, when the OSL method is applied to the internal deposits of terraces, have both been shown to be inaccurate (Gibson, 2015; Gibson \& Lewis, 2017). Hence, a combination of evidence must be used for dating purposes, in line with commonly-agreed archaeological principals, and Landscape Archaeology is the best method for doing this (Gibson, 2003). The same may be said for the dating of terracing using the OSL method which only provides information about their final use. Since terraces were constantly reused over thousands of years, this is not a very helpful method for trying to clarify a picture of the history of terraces and their origin. Another mistake is to assume that terraces in all periods of antiquity looked the same, in terms of appearance and construction. This is not the case (for the variations of terrace types: Gibson, 2015: 298-300).

The working hypothesis that we adopt is that various centers of origin for terrace construction probably existed in the Near East, with Israel/Palestine being one of them, and that this occurred in the proto-historic period $\left(4^{\text {th }}\right.$ millennium B.C.E. $)$, at the time when horticulture flourished and plough-agriculture was introduced. Spencer and Hale have suggested various forms of incipient terracing/slope stabilization, such as soil held in place by logs of wood, by rows of wooden stakes, or piles of rocks (Spencer \& Hale, 1961: 3, 15 and note 16). These would be difficult to detect in the archaeological record, but it was probably recognized very early on that obstructions placed across a stream channel would help towards stopping the movement of eroded soils and thus would induce a process of alluviation. One may also suggest that early slope terracing took place initially in the lower parts of hillslopes, closer to the wadi beds which were also terraced, with newer terraces later being built further up the slopes following woodland removal. Suggestions have also been made that the natural step-like appearance of the rocky slopes of hills, with thin layers of chalky marl interposed between limestone or dolomite strata, may have prompted early attempts at terracing (Wilson, 1906: 200: Dalman, 1932: 23; Meshel, 1987; Orni \& Efrat, 1980: 55), and this may indeed be part of the fluid narrative relating to the early beginnings of terracing (Doolittle, 1990; Williams, 1990).

We suggest that patch cultivation/box fields were undoubtedly in use on deforested slopes, at least from the Chalcolithic period, and that as horizontal cultivation surfaces established on sloping ground, they most likely had a decisive role on the subsequent development of hillslope terracing. This is particularly clear at sites such as Ta'oz in the Judean Shephela (Figs. 5-7). The spread of terracing had to have been a function of topography, site location, contention over territory, and population growth. Admittedly, agriculture could have been 
practiced without terracing in any of the sub-regions of the highlands of the southern Levant (as suggested by Hopkins, 1985: 180; Gadot et al., 2015), but such a mismanagement of the soil resources on hillslopes would have led to a rapid and devastating erosion of soils, which makes this scenario highly unlikely.

Fig. 5: Aerial photograph of Chalcolithic cupmarks and box or patch fields at Ta'oz in the Judean Shephela, Israel. (Photo Rafael. Y. Lewis)

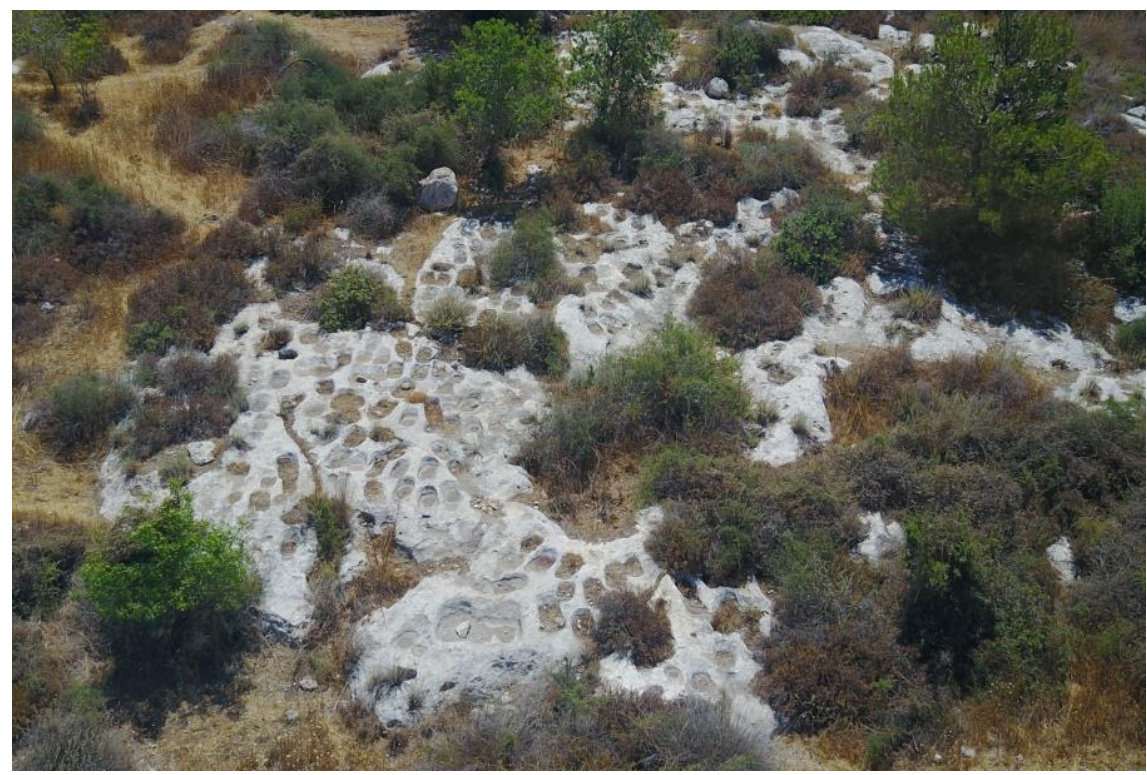

Fig. 6: Aerial photograph of Chalcolithic cupmarks and box or patch fields at Ta'oz in the Judean Shephela, Israel. (Photo Rafael. Y. Lewis)

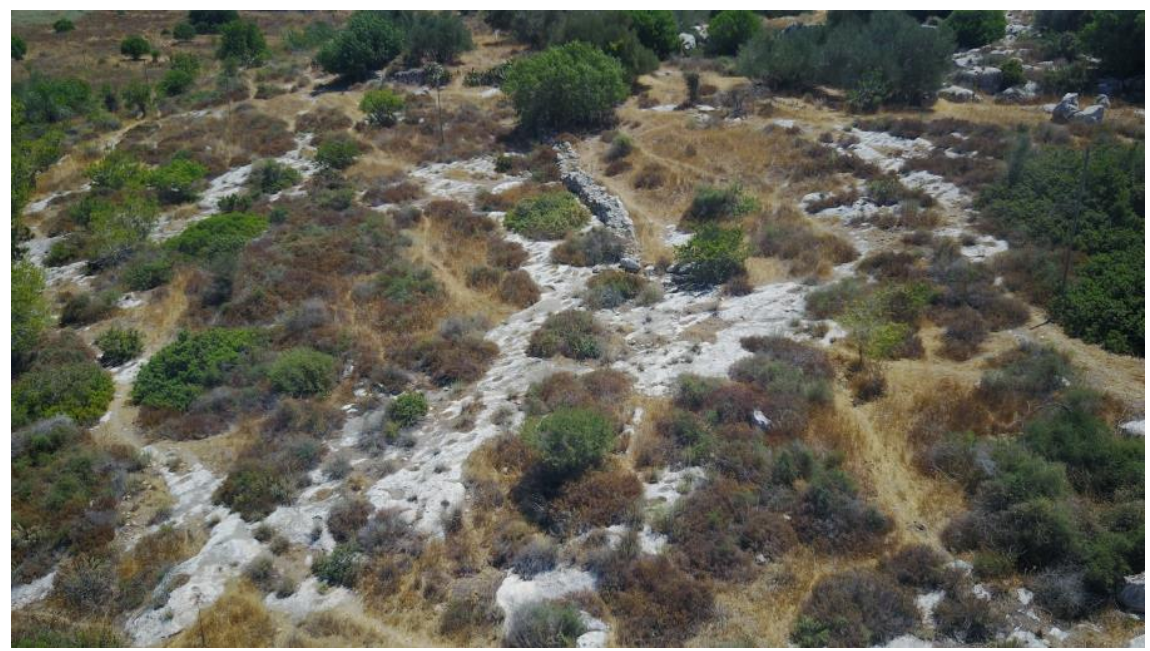


Fig. 7: Chalcolithic cupmarks surrounding small box fields with later terrace/field wall at Ta'oz in the Judean Shephela, Israel. (Photo Rafael. Y. Lewis)

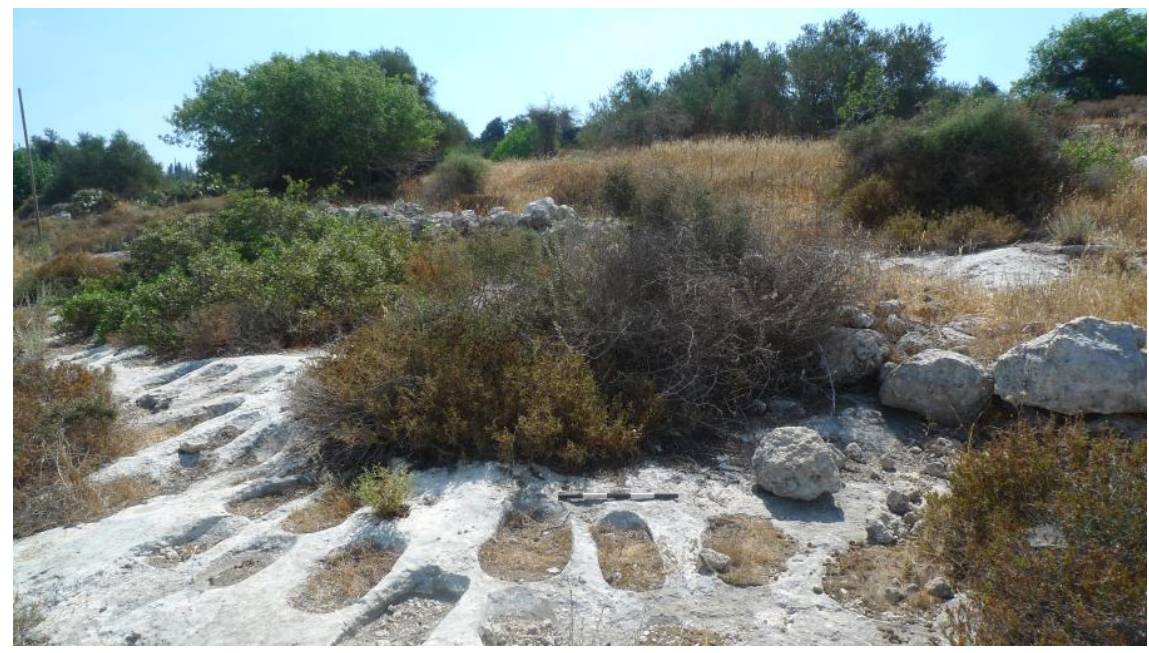

\section{REFERENCES}

Albright, W. F., (1961). The Archaeology of Palestine. Revised ed. Harmondsworth: Penguin.

Allen, J., (1970). Prehistoric Agricultural Systems in the Wahgi Valley: A Further Note. Mankind 7: 177-183.

Allen, M. J., (1971). Analysing the Landscape: A Geographical Approach to Archaeological Problems. Pp. 39-57 in A. J. Schofield (ed.), Interpreting Artefact Scatters: Contributions to Ploughzone Archaeology. Oxford: Oxbow.

Bevan, A., J. Conolly, S. Colledge, et al. (2013). The Long-Term Ecology of Agricultural Terraces and Enclosed Fields from Antikythera, Greece. Human Ecology 41: 255-272.

Dalman, G., (1932). Arbeit und Sitte in Palästina. Vol. II. Gütersloh.

Davidovich, U., N. Porat, Y. Gadot, Y. Avni, and O. Lipschits, (2012). Archaeological Investigations and OSL Dating of Terraces at Ramat Rahel, Israel. Journal of Field Archaeology 37: 192-208.

Donkin, R. A., (1979). Agricultural Terracing in the Aboriginal New World. Viking Fund Publications in Anthropology No. 56. Tuscon: University of Arizona.

Doolittle, W. E., (1990). Terrace origins: Hypotheses and Research Strategies. Yearbook. Conference of Latin Americanist Geographers 16: 94-97.

Fall, P. L., S. E. Falconer, C. S. Galletti, T. Shirmang, E. Ridder, and J. Klinge, (2012). Long-term Agrarian Landscapes in the Troodos Foothills, Cyprus, Journal of Archaeological Science 39: 2335-2347.

Finkelstein, I., (1988). The Archaeology of the Israelite Settlement. Jerusalem: IES.

Frederick, C. D., and A. Krahtopoupou, (2000). Deconstructing Agricultural Terraces: Examining the Influence of Construction Method on Stratigraphy, Dating and Archaeological Visibility. Pp. 79-94 in P. Halstead, and C. Frederick (eds.), Landscape and 
Land Use in Postglacial Greece. Sheffield.

Gadot, Y., U. Davidovich, G. Avni, Y. Avni, N. Porat, (2015). The Formation of a Mediterranean Terraced Landscape: The Case of Nahal Refa'im, Jerusalem. Pp. 118-142 in G. D. Stiebel, O. Peleg-Barkat, D. Ben-Ami and Y. Gadot (eds.), New Studies in the Archaeology of Jerusalem and its Region. Vol. 9 (Hebrew).

Gadot, Y., U. Davidovich, G. Avni, Y. Avni, M. Piasetzky, G. Feirstein, D. Golan, and N. Porat, (2016). The Formation of a Mediterranean Terraced Landscape, Mount Eitan, Judean Highlands, Israel. Journal of Archaeological Science: Reports 6: 397-417.

Galletti, C. S., E. Ridder, S. E. Falconer, and P. L. Fall, (2013). Maxent Modeling of Ancient and Modern Agricultural Terraces in the Troodos Foothills, Cyprus, Applied Geography 39: 46-56.

de Geus, C. H. J., (1975). The Importance of Archaeological Research into the Palestinian Agricultural terraces, with an Excursus on the Hebrew Word gbi. Palestine Exploration Quarterly 107: 65-74.

Gibson, S., (1995). Landscape Archaeology and Ancient Agricultural Field Systems in Palestine. Ph.D. Thesis, University College of London.

Gibson, S., (2001). Agricultural Terraces and Settlement Expansion in the Highlands of Early Iron Age Palestine: Is There Any Correlation between the Two? Pp. 113-146 in A. Mazar (ed.), Studies in the Archaeology of the Iron Age in Israel and Jordan. Journal for the Study of the Old Testament Supplement Series 331. Sheffield: Sheffield Academic Press.

Gibson, S., (2003). From Wildscape to Landscape: Landscape Archaeology in the Southern Levant - Methods and Practice. Pp. 1-25 in A. M. Maier, S. Dar, and Z. Safrai (eds.), The Rural Landscape of Ancient Israel. BAR Int. Series 1121. Oxford.

Gibson, S., (2015). The Archaeology of Agricultural Terraces in the Mediterranean Zone of the Southern Levant and the Use of the Optically Stimulated Luminescence Dating Method. Pp. 295-314 in: B. Lucke, R. Bäumler, M. Schmidt, (eds.), Soils and Sediments as Archives of Environmental Change. Geoarchaeology and Landscape Change in the Subtropics and Tropics. Erlanger Geographische Arbeiten Band 42.

Gibson, S., B. Ibbs, and A. Kloner, (1991). The Sataf Project of Landscape Archaeology in the Judaean Hills: A Preliminary Report on Four Seasons of Survey and Excavation (1987-89). Levant 23: 29-54.

Gibson, S., and R. Y. Lewis, (2017). On Determining the Date of Agricultural Terraces Around Jerusalem. Pp 281-301 in E. Baruch and A. Faust (eds.), New Studies on Jerusalem. Vol. 22. Ramat Gan: Bar-Ilan University (Hebrew).

Gibson, S. and Y. M. Rowan, (2006). The Chalcolithic in the Central Highlands of Palestine: A Reassessment Based on a New Examination of Khirbet es-Sauma'a. Levant 38: 85-108.

Hopkins, D. C., (1985). The Highlands of Canaan: Agricultural Life in the Early Iron Age. Sheffield: Almond.

Korobov, D. S., and A. V. Borisov, (2013). The Origins of Terraced Field Agriculture in the Caucasus: New Discoveries in the Kislovodsk Basin. Antiquity 87: 1086-1103.

Kuijt, I., B. Finlayson, and J. Mackay, (2007). Pottery Neolithic Landscape Modification at Dhra'. Antiquity 81: 106-118.

Meshel, Z., (1987). Are Terraces Part of the Natural Landscape? In Z. Avni (ed.), Agricultural Terraces in the Judean Hills. Proceedings of the JNF Conference, Sataf. Jerusalem: JNF (Hebrew). 
Orni, E., and E. Efrat, (1980). Geography of Israel. $4^{\text {th }}$ revised ed. Jerusalem: Israel universities.

Perry, W. J., (1916). The Geographical Distribution of Terraced Civilization and Irrigation. Memoirs and Proceedings of the Manchester Literary and Philosophical Society 60: 1-25.

Pfann, S., R. Voss, Y. Rapuano, (2007). Surveys and Excavations at the Nazareth Village Farm (1997-2002): Final Report. Bulletin of the Anglo-Israel Archaeological Society 25: 19-79.

Porat, N., U. Davidovich, Y. Avni, G. Avni, Y. Gadot, (2017). Using OSL Measurements to Decipher Soil History in Archaeological Terraces, Judean Highlands, Israel. Land Degradation \& Development, DOI: 10.1002/Idr.2729.

Ron, Z. Y. D., (1966). Agricultural Terraces in the Judean Mountains. Israel Exploration Journal 16: 33-49, 111-122.

Ron, Z. Y. D., (1977). The Distribution of Agricultural Terraces in the Hills of Jerusalem. Pp. 210-229 in A. Shmueli, D. Grossman, and R. Zeevi, (eds.), Judea and Samaria: Studies in Settlement Geography. Vol. I, Jerusalem: Canaan (Hebrew).

Spencer, J. H., and G. A., Hale, (1961). The Origin, Nature and Distribution of Agricultural Terracing. Pacific Viewpoint 2: 1-40.

Van den Brink, E. C. M., (2008). A New Fossile Directeur of the Chalcolithic Landscape in the Shephelah and the Samarian and Judaean Hill Countries: Stationary Grinding facilities in Bedrock, Israel Exploration Journal 58 (1): 1-23.

Wheatley, P., (1965). Agricultural Terracing. Pacific Viewpoint 6: 123-144.

Wilkinson, T. J., (2003). Archaeological Landscapes of the Near East. University of Arizona Press: Tucson.

Williams, L. S., (1990). Agricultural Evolution in Latin America. Yearbook. Conference of Latin Americanist Geographers 16: 82-93.

Wilson, C. T., (1906). Peasant Life in the Holy Land. London: Murray.

Wright, A. C. S., (1962). Some Terrace Systems of the Western Hemisphere and Pacific Islands. Pacific Viewpoint 3: 97-100. 